Asian J Agric \& Biol. 2021(2).

\title{
Decomposition rate and litterfall dynamics of Tembawang agroforestry area, West Kalimantan, Indonesia
}

\author{
Rafdinal $^{1 *}$, Ramadanil Ramadanil ${ }^{2}$, Adityo Raynaldo ${ }^{3}$, Eko Subrata ${ }^{4}$ \\ ${ }^{1}$ Department of Biology, Faculty of Mathematics and Natural Sciences, Tanjungpura University, Pontianak, West \\ Kalimantan, 78124, Indonesia \\ ${ }^{2}$ Department of Biology, Faculty of Mathematics and Natural Sciences, Tadulako University, Palu, Central Sulawesi, 94148, \\ Indonesia \\ ${ }^{3}$ Department of Marine Science, OSO University, Pontianak, West Kalimantan, 78124, Indonesia \\ ${ }^{4}$ Department of Forestry, Faculty of Forestry, Muhammadiyah Sumatera Barat University, Padang, West Sumatra, 25172, \\ Indonesia
}

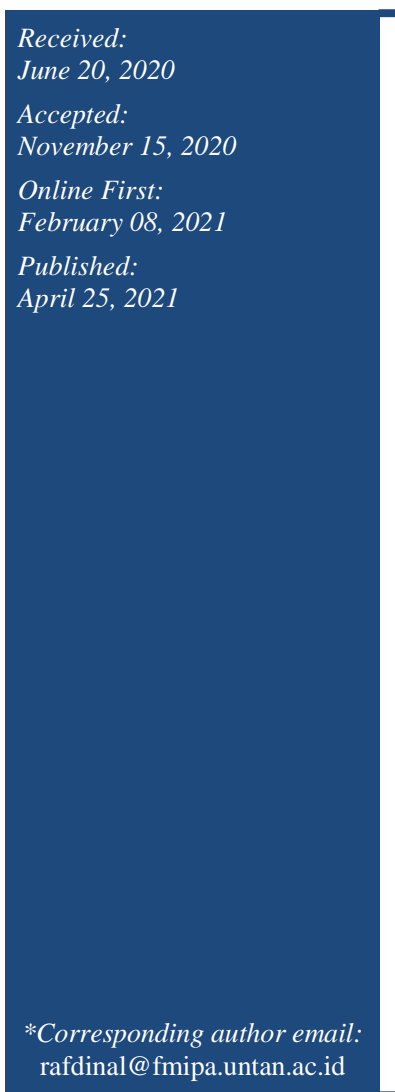

\begin{abstract}
Understanding the carbon cycle could be the basis and best way to management practices in traditional agroforestry. In this study, we will estimate the litterfall dynamics and decomposition rate in one of the traditional agroforestry 'Tembawang' practiced by local people in Kalimantan. Litterfall dan decomposition monitoring was conducted every two weeks for three months with litterfall traps and litterbags. From the results, we found litterfall production of Tembawang Agroforestry was 91.23-95.03 gr m ${ }^{-2}$ month $^{-1}$ or 10.95-11.40 tons ha-1 year-1. The estimated litter decomposition rate in the first of 14 days was 3.92-4.43 gram day $^{-1}$ after that decomposition rate decreased (on $84^{\text {th }}$ day) at $0.75-0.81$ gram day $^{-1}$. A positive Spearman correlation occurred with the rainfall and temperature variables on the dynamics of litterfall but the value was not significant. Tembawang agroforestry litter production is higher than another agroforestry and the value is approaching the primary tropical rainforest. Litter decomposed more than 50 percent in the initial two weeks and the value is correlated to humidity.
\end{abstract}

Keywords: Carbon cycle, Fruit Tembawang, Rubber Tembawang, Traditional agroforestry, Sekadau Regency

\section{How to cite this:}

Rafdinal, Ramadanil R, Raynaldo A and Subrata E, 2021. Decomposition rate and litterfall dynamics of Tembawang agroforestry area, West Kalimantan, Indonesia. Asian J. Agric. Biol. 2021(2): 202006350. DOI: https://doi.org/10.35495/ajab.2020.06.350

This is an Open Access article distributed under the terms of the Creative Commons Attribution 3.0 License. (https://creativecommons.org/licenses/by/3.0), which permits unrestricted use, distribution, and reproduction in any medium, provided the original work is properly cited.

\section{Introduction}

The role of tropical forests in the carbon cycle in the atmosphere is determined by the amount of carbon contained in biomass and carbon sequestration rate per year. The carbon of tropical forest biomass is generally released through respiration into the atmosphere (Murdiyarso and Satjapradja, 1997). Tropical forest ecosystems play an important role in global carbon sequestration. Carbon intake in different vegetation occurs through photosynthesis and enhances by environmental factors and good forest management 
practices. Deforestation is an activity that can change forest land use. This activity will directly impact the heat transfer from and to the surface of the forest and thus have an impact on energy balances, water balances, and nutrient balances of the forest (Murdiyarso and Satjapradja, 1997).

Litter decomposition is a very important process in nutrient dynamics in forest ecosystems (Regina and Tarazona, 2001). The litter decomposition process involves many factors including environmental factors such as $\mathrm{pH}$ (Van Breemen, 1995); climate (temperature, humidity) (Guo and Sims, 1999); chemical composition of litter (Aerts and Caluwe, 1997), and soil microorganisms (Saetre, 1998). In general, litter decomposition rate is generally slower under low $\mathrm{pH}$ soil than neutral $\mathrm{pH}$ (Murayama and Zahari, 1992). Moreover, Murayama and Zahari (1992) stated that a higher $\mathrm{C} / \mathrm{N}$ ratio in the litter was more difficult to decompose than a lower $\mathrm{C} / \mathrm{N}$ litter ratio. In general, litter from a plant that grows in nutrient-poor environments is more difficult to decompose and will cause a slower process of nutrient cycling in the environment than litter are from plants in nutrient-rich environments (Van Breemen, 1995; Aerts and Caluwe, 1997). Litter in highly microorganisms concentration areas tend to decompose more quickly than fewer microorganisms concentration areas (Saetre, 1998). The litter decomposition rate also takes place more rapidly under aerobic conditions than anaerobic conditions (Johnson and Damman, 1991).

The Tembawang Agroforestry area in West Kalimantan is a tropical forest which is managed by Dayak's tribe traditional communities. Tembawang Agroforestry is a forest plantation which is far located from the settlement. Tembawang Agroforestry can be classified into a forest garden because they look like a forest and contains various types of fairly large diameter trees (Arifin et al., 2003). Rafdinal and Pitopang (2019) reported that Tembawang Agroforestry has 43 species of plants consisted of 32 genera and 13 families. This agroforestry area is a potential non-woody timber forest that was preserved and maintained by the local community. The results of the study of Rafdinal and Pitopang (2019) also showed that there was a correlation between the density and basal area of the stand with the condition of soil fertility.

The productivity and sustainability in the nutrient cycle of Tembawang Agroforestry are interesting to study. A prospective analysis in this study is very important to determine the key factors in developing the optimal economic, social, and ecological functions of the Tembawang Agroforestry area in the future. The rehabilitation program of tembawang was carried out in several villages in several districts of West Kalimantan also has not been able yet to overcome the problem of adding forest value. The increasing land productivity through the study of the dynamics of decomposition and litterfall production related to carbon stocks and nutrient cycles is an appropriate alternative to increase Tembawang Agroforestry productivity, especially in assessing of global warming issue and optimizing the function of forests as environmental services, as well as increasing community income, especially in Sekadau Regency, West Kalimantan. This research aimed to estimate litterfall production, to analyze litter decomposition rate and to analyze litterfall dynamics of the Tembawang agroforestry area in Sekadau Regency, West Kalimantan, Indonesia.

\section{Material and Methods}

\section{Site description}

This research was conducted at the Tembawang Agroforestry area, Nanga Pemubuh Village, Sekadau Hulu District, Sekadau Regency, West Kalimantan. The Tembawang Agroforestry area has two types, namely fruit Tembawang and rubber Tembawang. Sekadau Hulu Subdistrict is one of seven subdistricts in Sekadau Regency which has $\pm 869.7 \mathrm{~km}^{2}$ with generally highland and fewer lowland areas. Geographically, Sekadau Hulu Subdistrict is located at $0^{\circ} 85^{\prime} 5^{\prime}-0^{\circ} 21^{\prime} 30^{\prime \prime} \mathrm{S}$ and $110^{\circ} 8^{\prime} 45^{\prime \prime}-111^{\circ} 15^{\prime} 20^{\prime \prime} \mathrm{E}$. The average rainfall in the Sekadau Hulu was between 1,684 to $12,000 \mathrm{~mm}$. The topography of Sekadau District was plain and hill forms with altitude 0-1,000 m above sea level (masl) (Fig 1).

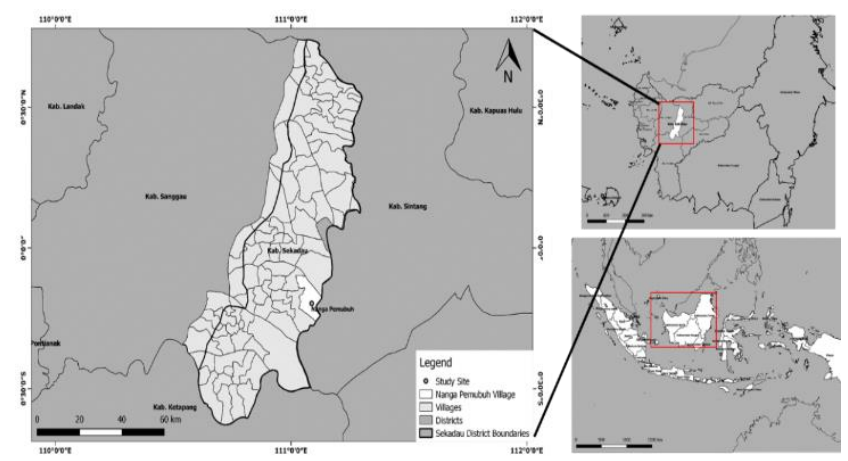

Figure-1. Research location at Tembawang Agroforestry, Sekadau Regency 


\section{Litterfall dynamics and nutrient cycle}

There are four blocks, each block consists of four sampling $50 \mathrm{~m} \times 50 \mathrm{~m}$ plots in relatively flatted Tembawang Agroforestry area. Each block was selected as a sample plot for research of litter and nutrient content. Litterfall traps were placed randomly in four samplings $50 \mathrm{~m} \times 50 \mathrm{~m}$ plots (each plot has 10 traps). The $1 \mathrm{~m} \times 1 \mathrm{~m}$ traps were made from a plastic net $(0.1 \mathrm{~cm}$ hole $)$ with a frame placed $1 \mathrm{~m}$ above the ground. The collected litter in each litter trap was put into a wheat bag and air-dried for at least 2 days. After drying, the litters of each bag were sorted into 4 parts of plants, following Proctor et al. (1983), namely (1) leaf (2) branch/twig (diameter $<2 \mathrm{~cm}$ ), (3) flower + fruit, and (4) mixed litters. The sorted litters were then weighted and combined into a litter combination for each part per month from each plot. The data analyzed was average litter gram $\mathrm{m}^{-2}$ month $^{-1}$. Then, each part was oven-dried at $105^{\circ} \mathrm{C}$ and re-weighed to get ovendried weight. Chemical analysis was carried out for all parts (leaf, branch, flower + fruit, and mixed litters). Before being analyzed, the samples were crushed using an electric grinding machine. At least, 0.2 grams of oven-dried weight of each sample was crushed and dissolved into $4.4 \mathrm{ml}$ of a solution made from $350 \mathrm{ml}$ of sulfuric acid, $420 \mathrm{ml}$ of hydrogen peroxide, 0.42 grams of selenium as a catalyst and 14 gram of lithium sulfate (Allen, 1989).

\section{The rate of nutrient decomposition and release in the Tembawang agroforestry}

The rate of nutrient decomposition and release of the Tembawang agroforestry area was measured by putting $100 \mathrm{~g}$ fresh litter into a net bag (with a size of $25 \times 22 \mathrm{~cm}$ ) placed on the forest floor, this intended to make the process of decomposition as natural as possible (Moore et al., 1984). The monitoring of litterbags was carried out at certain intervals to estimate the rate of litter mineralization (Haraguchi et al., 2002). 30 litterbags were placed at each research location where the litters were taken. Five replicate samples were taken every two weeks. After weighing, the dried leaf litters were oven-dried for 48 hours at $70^{\circ} \mathrm{C}$ to determine the ratio between air-dry weight and oven-dried weight for each sub-type of Tembawang Agroforestry, namely fruit Tembawang and rubber Tembawang. The nutrient release was calculated based on the formulation of Guo and Sims (1999); Guo and Sims (2001). The litter decomposition rate was calculated using the equation:

$$
\mathrm{R}=\frac{\mathrm{Wo}-\mathrm{Wt}}{\mathrm{T}}
$$

Remark:

$$
\begin{array}{ll}
\mathrm{R} & \text { : Decomposition rate }\left(\mathrm{g} \mathrm{day}^{-1}\right) \\
\mathrm{T} & \text { : Observation time }(\text { days }) \\
\mathrm{Wo} & \text { : Initial litter dry weight }(\mathrm{g}) \\
\mathrm{Wt} & \text { : Litter dry weight o after t-time }(\mathrm{g})
\end{array}
$$

The percentage of litter decomposition is obtained using the formula (Boonruang, 1984)

$$
\mathrm{Y}=\frac{\mathrm{Wo}-\mathrm{Wt}}{\mathrm{Wo}} \times 100 \%
$$

Remark:

Y : Percent of decomposed leaf litter

Wo : Initial litter dry weight $(\mathrm{g})$

Wt : Litter dry weight after time-t $(\mathrm{g})$

Estimation of litter decomposition rate constant is obtained using the formula (Ashton et al., 1999):

$$
\begin{gathered}
X_{t}=X_{0} e^{-K t} \\
\ln \left(X_{t} / X_{0}\right)=-K t
\end{gathered}
$$

Remark:

$\mathrm{X}_{\mathrm{t}} \quad$ : Litter weight after time $\mathrm{t}$ (days)

$\mathrm{X}_{0} \quad$ : Initial litter weight

E : Natural logarithm number (2.72)

$\mathrm{K}$ : Coefficient of decomposition

$\mathrm{T} \quad$ : Time (day)

\section{Data Analysis}

A comparison of litter production and decomposition rate for each pick-up period was analyzed using oneway ANOVA. The differences were evaluated at $\mathrm{P}$ $<0.05$. The relationship between the dynamics of litterfall and climate was analyzed using Spearman's regression and correlation. All statistical analyzes used the SPSS Graduate Pack ${ }^{\mathrm{TM}} 14.0$ program for Windows. A difference was evaluated at $\mathrm{P}<0.05$.

\section{Results and Discussion}

\section{The litterfall dynamics}

There were several tree species i.e. Durio zibethinus (Durian), Mangifera quadrifida (Asam Kemantan), Eleiodoxa conferta (Asam Paya), Garcinia celebica (Asam Manggis/Forest Mangosteen) at fruitTembawang and Hevea brasiliensis (Rubber) and 
Arthocarpus elasticus (Terap/Kepuak) at rubberTembawang. These plants contributed to the production of forest litter and natural soil nutrients. Durian tree (Durio zibethinus) was the dominant species found at the fruit Tembawang Agroforestry site and had the largest contribution to the production of litters at the location compared to other species.

The mean production of litterfall at the research location is presented in Table 1. Estimation results show the total litter production at the Tembawang fruit agroforestry location was $3.04 \pm 1.07$ gram m$^{-2}$ day $^{-1}$, and at the rubber-Tembawang location was 3.17 \pm 3.01 gram $\mathrm{m}^{-2}$ day $^{-1}$. If estimated in a year, the total litter production at study sites was estimated at 10.95-11.40 tons ha ${ }^{-1}$ year $^{-1}$.

Table-1. The average litterfall weight of Tembawang agroforestry

\begin{tabular}{|c|c|c|c|c|c|c|c|}
\hline Types & Leaf & Branch & $\begin{array}{l}\text { Generat } \\
\text { ive } \\
\text { organs }\end{array}$ & \begin{tabular}{|l} 
othe \\
rs
\end{tabular} & \begin{tabular}{|l|} 
Total \\
$\left(\mathbf{g} \mathbf{m}^{-2}\right.$ \\
day $\left.^{-1}\right)$
\end{tabular} & \begin{tabular}{|l|} 
Total $(\mathrm{g}$ \\
m $^{-2}$ \\
month $\left.^{-1}\right)$ \\
\end{tabular} & \begin{tabular}{|l} 
Total \\
(tons ha \\
'year $^{-1}$ ) \\
\end{tabular} \\
\hline it & 2.05 & 0.11 & 0.12 & 0.09 & 3.04 & 91.23 & 10.95 \\
\hline mber & 2.60 & 0.43 & 0.09 & 0.04 & 3.17 & 95.03 & 11.40 \\
\hline
\end{tabular}

Analysis of litter production based on parts of plants was divided into vegetative parts (leaves and branches), generative parts (flowers and fruits), and others (Fig 2). The leaf portion was the highest component in both locations (60-80 percent of all litter components). This was similar to Alhamd and Hagihara (2004), Salim and Budiadi (2014) where leaves were a dominant component of the whole litterfall components (more than 50 percent). This is related to the leaf is a dominant plant organ and is easily released organ due to direct contact with climatic factors such as rain and wind.
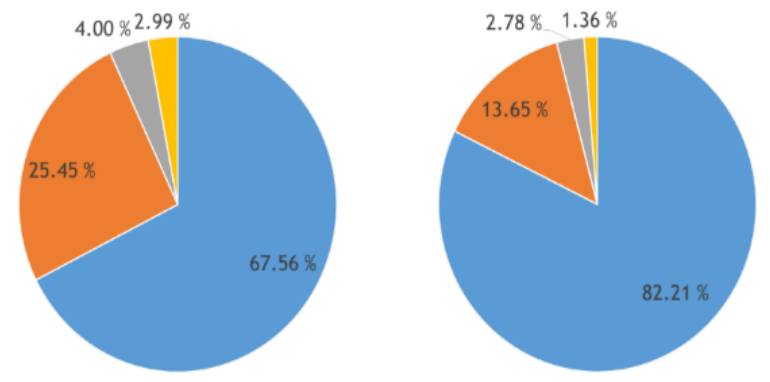

- Leaf $=$ Branch $\mid=$ Generative Organ $=$ Other $=$ Leaf $=$ Branch $\mid=$ Generative Organ $=$ Other

Figure-2. Percentage of litter production at fruit Tembawang agroforestry (left) and Rubber Tembawang agroforestry (right).

Litterfall production at both locations was related to climatic factors, especially rainfall, but it was not significant (Fig 5 and Table 3). In dry months such as June and August, litterfall production at both locations increases. In line with research from Tongkaemkaew et al. (2018) wherein the dry season litter production increases and vice versa.

Litter production of Tembawang agroforestry was from 10.95 to 11.40 tons ha $^{-1}$ year ${ }^{-1}$. This litter production was smaller than litter production in the tropical rainforest ecosystem reported by Songwe et al. (1988) and Triadiati et al. (2011). However, litter production at the study site was higher than the other ecosystems (Table 2). The litter production was mainly influenced by the fertility of the ecosystem where the higher the fertility of an ecosystem, the greater the production of litter (Triadiati et al., 2011). Ecosystem fertility is related to the high intensity of the generative phase of the types of ecosystems. When entering the generative phase (flowering), plants tend to fall more of their leaves due to the process of concentration of energy and growth components to support the formation of flowers.

Table-2. The comparison of litterfall production in several locations

\begin{tabular}{|c|c|c|}
\hline Locations & Ecosystem types & $\begin{array}{c}\text { Litterfall } \\
\text { production } \\
\text { (ton/ha/year) }\end{array}$ \\
\hline $\begin{array}{l}\text { Central Sulawesi, } \\
\text { Indonesia }\end{array}$ & $\begin{array}{l}\text { Tropical rain forest } \\
\text { Cacao Agroforestry }\end{array}$ & $\begin{array}{c}13.67^{1} \\
4.98-8.23^{1}\end{array}$ \\
\hline $\begin{array}{l}\text { Yogyakarta, } \\
\text { Indonesia }\end{array}$ & $\begin{array}{l}\text { Community forest } \\
\text { (Alas/forest, pekarangan } \\
\text { and tegalan) }\end{array}$ & $9.22-12.1^{2}$ \\
\hline Eurasia & $\begin{array}{l}\text { Tropical forest } \\
\text { Sub-tropical forest } \\
\text { Temperate forest } \\
\text { Boreal forest } \\
\end{array}$ & $\begin{array}{c}5.64-9.60^{3} \\
4.32-6.09^{3} \\
3.07-4.62^{3} \\
2.57^{3} \\
\end{array}$ \\
\hline Okinawa, Japan & $\begin{array}{l}\text { Evergreen Subtropical } \\
\text { forest }\end{array}$ & $6.66-8.28^{4}$ \\
\hline $\begin{array}{l}\text { Ashanti Region, } \\
\text { Ghana }\end{array}$ & $\begin{array}{l}\text { Primary and Secondary } \\
\text { forest } \\
\text { Cacao plantation }\end{array}$ & $\begin{array}{l}7.9^{5} \\
6.9^{5}\end{array}$ \\
\hline $\begin{array}{l}\text { Southwest, } \\
\text { Kamerun }\end{array}$ & Tropical rain forest & $12.9-14.1^{6}$ \\
\hline $\begin{array}{l}\text { West Kalimantan, } \\
\text { Indonesia }\end{array}$ & Tembawang Agroforestry & $10.95-11.40^{7}$ \\
\hline
\end{tabular}

Sources : 1) Triadiati et al. (2011), 2) Salim and Budiadi (2014), 3) Chun-jiang et al. (2003), 4) Alhamd and Hagihara (2004), 5) Owusu-Sekyere et al. (2006), 6) Songwe et al. (1988), 7) Present Study (2020) 


\section{Litter decomposition of Tembawang agroforestry}

The estimated results showed that process of litter decomposition of fruit Tembawang agroforestry was significant decomposition (more than 50 percent) on the first observation (fourteenth day) with an average decomposition rate was 4.13 grams day $^{-1}$ (Table 3 ). In the next observation, the decomposition rate tended to constantly decrease so that at the last observation (eighty-fourth day) the decomposed litter was approximately 68 percent. The average litter decomposition rates of fruit Tembawang agroforestry are presented in Table 3.

The average litter decomposition rates of rubber Tembawang Agroforestry location are presented in Table 4. Based on the estimated results, the highest decomposition rates occurred in the first two weeks, with average decomposition litter was 3.92 grams day ${ }^{1}$. The decomposition rate tended to decrease constantly every week so that at the end of the observation (eighty-fourth day), the dry litter weight was 36.76 grams or an average decomposition percentage was 63.24 percent of the initial weight.

Table-3. The average litter decomposition rate of fruit Tembawang agroforestry

\begin{tabular}{|c|c|c|c|c|c|}
\hline $\begin{array}{c}\text { Observ } \\
\text { ation } \\
\text { day }\end{array}$ & $\begin{array}{c}\text { Initia } \\
\text { I } \\
\text { weig } \\
\text { ht (g) }\end{array}$ & $\begin{array}{c}\text { Final } \\
\text { weight } \\
(\mathbf{g})\end{array}$ & $\begin{array}{c}\text { Decompo } \\
\text { sed leaves } \\
(\mathbf{g})\end{array}$ & $\begin{array}{c}\text { Decompose } \\
\text { d litterfall } \\
(\%)\end{array}$ & $\begin{array}{c}\text { Decomp } \\
\text { osition } \\
\text { rate (g } \\
\left.\text { day }^{-1}\right)\end{array}$ \\
\hline \multirow{2}{*}{14} & 100 & $\begin{array}{c}42.21 \pm \\
5.34\end{array}$ & $\begin{array}{c}57.79 \pm \\
5.34\end{array}$ & $\begin{array}{c}57.79 \pm \\
5.34\end{array}$ & $\begin{array}{c}4.13 \pm \\
0.38\end{array}$ \\
\hline \multirow{2}{*}{28} & \multirow{2}{*}{100} & $\begin{array}{c}37.49 \pm \\
6.78\end{array}$ & $\begin{array}{c}62.51 \pm \\
6.78\end{array}$ & $\begin{array}{c}62.51 \pm \\
6.78\end{array}$ & $\begin{array}{c}2.23 \pm \\
0.24\end{array}$ \\
\hline \multirow{2}{*}{42} & \multirow{2}{*}{100} & $\begin{array}{c}37.81 \pm \\
5.00\end{array}$ & $\begin{array}{c}62.19 \pm \\
5.00\end{array}$ & $\begin{array}{c}62.19 \pm \\
5.00\end{array}$ & $\begin{array}{c}1.48 \pm \\
0.12\end{array}$ \\
\hline \multirow{2}{*}{56} & \multirow{2}{*}{100} & $\begin{array}{c}33.84 \pm \\
2.04\end{array}$ & $\begin{array}{c}66.16 \pm \\
2.04\end{array}$ & $\begin{array}{c}66.16 \pm \\
2.04\end{array}$ & $\begin{array}{c}1.18 \pm \\
0.04\end{array}$ \\
\hline \multirow{2}{*}{70} & \multirow{2}{*}{100} & $\begin{array}{c}33.74 \pm \\
7.46\end{array}$ & $\begin{array}{c}66.26 \pm \\
7.46\end{array}$ & $\begin{array}{c}66.26 \pm \\
7.46\end{array}$ & $\begin{array}{c}0.95 \pm \\
0.11\end{array}$ \\
\hline \multirow{2}{*}{84} & \multirow{2}{*}{100} & $\begin{array}{c}31.64 \pm \\
2.19\end{array}$ & $\begin{array}{c}68.36 \pm \\
2.19\end{array}$ & $\begin{array}{c}68.36 \pm \\
2.19\end{array}$ & $\begin{array}{c}0.81 \pm \\
0.03\end{array}$ \\
\hline
\end{tabular}

The rate of litter decomposition is related to climatic factors at the location such as rainfall. In conditions of increased rainfall, the rate of decomposition increases and vice versa, but is not significant (Fig 5 and Table 3 ). In line with the research of Singhal et al. (2019) where the rate of litter decomposition increases during the rainy season. This is related to the physical properties and microbial activity in humid conditions, so the microbial activity in decomposing will increase.
Table-4. The average litter decomposition rate of rubber Tembawang agroforestry

\begin{tabular}{|c|c|c|c|c|c|}
\hline $\begin{array}{c}\text { Observa } \\
\text { tion } \\
\text { day }\end{array}$ & $\begin{array}{c}\text { Initial } \\
\text { weigh } \\
\mathbf{t}(\mathbf{g})\end{array}$ & $\begin{array}{c}\text { Final } \\
\text { weight }(\mathbf{g})\end{array}$ & $\begin{array}{c}\text { Decompose } \\
\mathbf{d} \text { leaves }(\mathbf{g})\end{array}$ & $\begin{array}{c}\text { Decompose } \\
\mathbf{d} \text { litterfall } \\
(\%)\end{array}$ & $\begin{array}{c}\text { Decomposi } \\
\text { tion rate }(\mathbf{g} \\
\left.\text { day }^{-1}\right)\end{array}$ \\
\hline 14 & 100 & $\begin{array}{c}45.14 \pm \\
4.09\end{array}$ & $54.86 \pm 4.09$ & $54.86 \pm 4.09$ & $3.92 \pm 0.29$ \\
\hline 28 & 100 & $\begin{array}{c}43.22 \pm \\
6.50\end{array}$ & $56.78 \pm 6.50$ & $56.78 \pm 6.50$ & $2.03 \pm 0.23$ \\
\hline 42 & 100 & $\begin{array}{c}39.27 \pm \\
7.81\end{array}$ & $60.73 \pm 7.81$ & $60.73 \pm 7.81$ & $1.45 \pm 0.19$ \\
\hline 56 & 100 & $\begin{array}{c}41.34 \pm \\
5.63\end{array}$ & $58.66 \pm 5.63$ & $58.66 \pm 5.63$ & $1.05 \pm 0.10$ \\
\hline 70 & 100 & $\begin{array}{c}43.67 \pm \\
3.48\end{array}$ & $56.33 \pm 3.48$ & $56.33 \pm 3.48$ & $0.80 \pm 0.05$ \\
\hline 84 & 100 & $\begin{array}{c}36.76 \pm \\
5.01\end{array}$ & $63.24 \pm 5.01$ & $63.24 \pm 5.01$ & $0.75 \pm 0.06$ \\
\hline
\end{tabular}

The decomposition process that occurred in both locations tended to have a similar trend where the significant decomposition process occurs in the first two weeks with the percentage of litter decomposition was more than 50 percent. Furthermore, the rate of decomposition at both locations was constantly declined and at the end of the observation, more than 60 percent of the litter had been decomposed. These results were similar to the decomposition process in natural forests and cocoa agroforestry in Central Sulawesi (Triadiati et al., 2011). At the last observation, decomposed litter was about 60 percent. In line with the research of Triadiati et al. (2011) and Songwe et al. (1988), the decomposition process was very quickly at the beginning of the observation and was significantly slowdown in subsequent observations. This was due to the initial content of litterfall still contained a lot of water or dissolved compounds in water that were easily decomposed.

The relationship between climate factors and litter decomposition

A graph of monthly climate factors was presented in Fig 3. In 2016-2017, the range of rainfall from May to August at Sekadau Regency was from 161.50 to $323.55 \mathrm{~mm}$. The average air temperature was from 27.65 to $27.8^{\circ} \mathrm{C}$ and the average humidity was from 86.35 to 87.70 percent (CBS Sekadau Regency, 2017; CBS Sekadau Regency, 2018). 


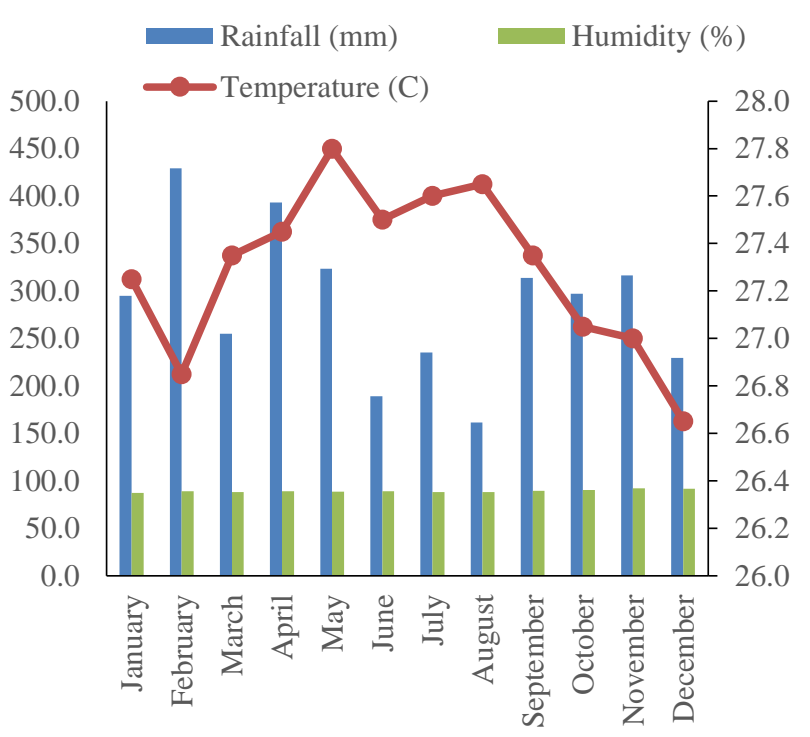

Figure-3. Climate factor (Rainfall, Humidity and Temperature) at Sekadau Regency in 2016-2017

The results of Spearman correlation analysis between litter production and decomposition with climate variables were presented in Table 5. All test variables have no significant correlation $(\mathrm{p}<0.05)$ except for the correlation between humidity factor and litter decomposition was significant. The rainfall and temperature factors have a positive correlation to litter decomposition of fruit Tembawang Agroforestry with a correlation value of more than 0.7 but not significant.

Table-5. Correlation matrix between climate factors with production and decomposition of Tembawang forest litter

\begin{tabular}{|l|c|c|}
\hline \multirow{2}{*}{ Variables } & \multicolumn{2}{c|}{ Locations } \\
\cline { 2 - 3 } & $\begin{array}{c}\text { Fruit } \\
\text { Tembawang }\end{array}$ & $\begin{array}{c}\text { Rubber } \\
\text { Tembawang }\end{array}$ \\
\hline $\begin{array}{l}\text { Rainfall and litterfall } \\
\text { production }\end{array}$ & $-0.774^{\text {ns }}$ & -0.689 \\
\hline $\begin{array}{l}\text { Temperature and } \\
\text { litterfall production }\end{array}$ & $-0.178^{\text {ns }}$ & -0.027 \\
\hline $\begin{array}{l}\text { Humidity and litterfall } \\
\text { production }\end{array}$ & -0.441 & -0.575 \\
\hline $\begin{array}{l}\text { Rainfall and litterfall } \\
\text { decomposition }\end{array}$ & 0.747 & 0.449 \\
\hline $\begin{array}{l}\text { Temperature and } \\
\text { litterfall } \\
\text { decomposition }\end{array}$ & 0.755 & 0.459 \\
\hline $\begin{array}{l}\text { Humidity and litterfall } \\
\text { decomposition }\end{array}$ & 0.954 & $0.997^{*}$ \\
\hline
\end{tabular}

Remark: ns (not significant) and * (significant correlation at $\mathrm{p}<0.05)$

\section{Conclusion}

Litter production of Tembawang Agroforestry in the Sekadau Regency was sufficient to contribute to the nutrient cycle. Although litter production was smaller than litter production in tropical rainforest ecosystems, the contribution of litter production can be an alternative to increase the natural fertility of the forest floor. Ecosystem fertility is related to the high intensity of the generative phase of types of ecosystems. When entering the generative phase (flowering), plants tend to fall more leaves due to the process of concentration of energy and growth components to support their flower formation. The decomposition process of two types of Tembawang Agroforestry tended to have a similar trend where a significant decomposition process occurred in the first two weeks with the percentage of litter decomposed more than 50 percent. Furthermore, the rate of decomposition at both sites was constantly declined and, at the end of the observation, more than 60 percent of litters were decomposed.

\section{Acknowledgment}

The authors are grateful to the Indonesian Government that funded this research through the Directorate of Research and Community Service, Directorate General of Research and Technology Strengthening, Ministry of Research, Technology and Higher Education. The authors would like to thanks Alinus, Adityo Raynaldo, Harmono, and Lia Utami Rahman for assisting in sampling.

Disclaimer: None.

Conflict of Interest: None.

Source of Funding: This research was funded by Directorate of Research and Community Service, Directorate General of Research and Technology Strengthening, Ministry of Research, Technology and Higher Education of Indonesia under grant No. 098/SP2H/LT/2018.

\section{References}

Aerts R and Caluwe HD, 1997. Nutritional and Plantmediated controls on leaf litter decomposition of Carex species. Ecology. 78: 244-260. 
Alhamd L and Hagihara A, 2004. Litterfall of a Subtropical Evergreen Broad-leaved Forest in Okinawa Island, Japan. Tropics. 13(4): 255-268.

Allen SE, 1989. Chemical Analyses of Ecological Materials. Blackwell Scientific Publications, Oxford, London.

Arifin HS, Sardjono MA, Sundawati S, Djogo T, Wattimena GA and Widianto, 2003. [Agroforestri di Indonesia]. World Agroforestry Centre (ICRAF), Jakarta. [in Indonesian]

Ashton EC, Hogarth PJ and Ormond R, 1999. Breakdown of mangrove leaf litter in a managed mangrove forest in Peninsular Malaysia. Hydrobiologia. 413: 77-88.

Boonruang P, 1984. The rate of degradation of mangrove leaves, Rhizophora apiculata $\mathrm{B}$. L. and Avicennia marina (Forsk) Vierh. at Phuket Island, western Peninsula of Thailand, pp. 200-208. In Proceeding Asian Symp. Mangr. Environ. Res. Manage. UNESCO.

Central Bureau of Statistic (CBS) of Sekadau Regency, 2017. Kabupaten Sekadau Dalam Angka 2017. CBS Sekadau Regency, West Kalimantan. [in Indonesian]

Central Bureau of Statistic (CBS) of Sekadau Regency, 2018. Kabupaten Sekadau Dalam Angka 2018. CBS Sekadau Regency, West Kalimantan. [in Indonesian]

Chun-jiang L, Ilversniemi H, Berg B, Kutsch W, Yusheng Y, Xiang-qing M and Westman CJ, 2003. Aboveground Litterfall in Eurasian Forests. J. Forest. Res. 14(1): 27-34.

Guo LB and Sims REH, 1999. Litter decomposition and nutrient release via litter decomposition in New Zealand eucalypt short rotation forests. Agric. Ecosyst. Environ. 75: 133-140.

Guo LB and Sims REH, 2001. Effects of light, temperature, water and meatworks effluent irrigation on eucalypt leaf litter decomposition under controlled environmental conditions. Appl. Soil. Ecol. 17: 229-237.

Haraguchi A, Kojima H, Hasegawa C, Takahashi Y and Iyobe T, 2002. Decomposition of organic matter in peat soil in a minerotrophic mire. Eur. J. Soil. Biol. 38: 89-95.

Johnson LC and Damman AWH, 1991. Speciescontrolled sphagnum decay on a south Swedish raised bog. Oikos. 61: 234-242

Moore TR, Bubier JL, Frolking SE, Lafleur PM and Roulet NT, 1984. Plant biomass and roduction and $\mathrm{CO}^{2}$ exchange in an ombrotrphic bog. J. Ecol. 90: 25-36.

Murayama S and Zahari AB, 1992. Biochemical decomposition of tropical forest. In Proceeding of the International Symposium on Tropical Peatland, pp. 124-133. Kuching. Sarawak, Malaysia.

Murdiyarso D and Satjapradja O, 1997, [The Impact of Tropical Forest Clearing on Climate Variations, in Water Resources and Climate in Creating Efficient Agriculture], Cooperation between the Department of Agriculture and the Indonesian Association of Agricultural Meteorology (PERHIMPI). [In Indonesian].

Owusu-Sekyere E, Cobbina J, and Wakatsuki T, 2006. Nutrient Cycling in Primary, Secondary Forests and Cocoa Plantation in the Ashanti Region, Ghana. Wajae. 9: 10-18.

Proctor J, Andeson JM, Fogden SCL and Vallack HW, 1983. Ecological studies in four contrasting lowland rain forest in Gunung Mulu National park, Sarawak. II. Litterfall, Llitter-standing crop and preliminary bservations on herbivory. J. Ecol. 71: 261-283.

Rafdinal and Pitopang R, 2019. The phytososiological of agroforestry Tembawang at secundary forest Sekadau Hulu in West Kalimantan Indonesia, pp. 1-6. In IOP Conf. Series: J. Physic.: Conf. Series 1242 (2019) 012041 IOP Publishing.

Regina IS and Tarazona T, 2001. Nutrient pools to the soil through organic matter and throughfall under a Scot pine plantation in the Sierra de la Demanda, Spain. Eur. J. Soil. Biol. 37: 125-133.

Saetre P, 1998. Decomposition, microbial community strusture, and earthworm effects along a birchspure soil gradient. Ecology. 79: 834-846.

Salim AG and Budiadi, 2014. [Litter Production and Content in Nglanggeran Communities Forest, Gunung Kidul, Yogyakarta]. JPHT. 11(2): 77-88. [In Indonesian].

Singhal V, Roy T, Singh C, Gosh J and Bhat S, 2019. Leaf litter production and decomposition dynamics in four agroforestry tree species of western Himalayas. J. Pharmacog. Phytochem. 2: 198-201.

Songwe NC, Fasehun FE and Okali DUU, 1988. Litterfall and Productivity in a Tropical Rain Forest, Southern Bakundu Forest Reserve, Cameroon. J. Trop. Ecol. 4: 25-37.

Tongkaemkaew U, Sukkul J, Sumkhan N, Panklang P, Brauman A and Ismail R, 2018. Litterfall, litter 
decomposition, soil macrofauna, and nutrient content in rubber monoculture and rubberbased agroforestry plantations. Forest Soc. 2(2): 138149.

Triadiati, Tjitrosemito S, Guhardja E, Sudarsono, Qayim I and Leuschner C, 2011. Litterfall Production and Leaf-litter Decomposition at Natural Forest and Cacao Agroforestry in Central Sulawesi, Indonesia. AJBS. 4(3): 221-234.

Van Breemen N, 1995. Nutrient cycling strategies. Plant. Soil. 168-169: 321-326.

\section{Contribution of Authors}

Rafdinal: Conceived idea, designed research methodology, data collection, data analysis and manuscript writing

Ramadanil R: Statistical analysis, literature review and manuscript writing

Raynaldo A: Data collection, data interpretation, literature search and manuscript writing Subrata E: Literature review, data interpretation, manuscript writing, manuscript final reading and approval 